Brit. J. vener. Dis. (1966), 42, 44.

\title{
SELF-MEDICATION BY PATIENTS ATTENDING A VENEREAL DISEASES CLINIC*
}

\author{
BY \\ KEVIN ANDERSON \\ Royal Adelaide Hospital, Adelaide, South Australia
}

Trafficking in certain drugs is well recognized in the majority of communities, being largely confined to compounds liable to produce addiction, such as morphine, heroin, barbiturates, and amphetamine. The efficacy of certain orally-administered antibiotics for the treatment of gonorrhoea is now widely known, and although these substances can normally be obtained only on prescription, there is every reason to suspect that other avenues of supply are available. Self-medication is attractive to the patient who wishes to avoid attending a clinic for investigation and treatment, but the dangers of this practice are real, and include inadequate dosage, the emergence of resistant strains of $N$. gonorrhoeae, and the possible masking of a concomitant syphilitic infection.

This investigation was undertaken to determine whether the unauthorized use of antibiotics could be detected in patients attending a venereal diseases clinic and, if so, whether the source of supply could be identified.

\section{Clinical Material}

Patients attending male and female clinics with no history of recent antibiotic therapy were selected for study. Most of them were making their first visit to the clinic for diagnosis, although several gave a history of previous attendances for investigation and treatment. All were diagnosed as suffering from acute gonococcal infection.

\section{Laboratory Methods}

It was decided that oral penicillin and sulphonamide compounds were the two antimicrobial drugs most likely to be available to patients for self-treatment. Blood was withdrawn by venepuncture, and $3 \mathrm{ml}$. were added to a bottle containing dipotassium sequestrene. The remaining blood was allowed to clot and the serum separated by centrifugation with a minimum of delay. Sera were stored at $-20^{\circ} \mathrm{C}$. and whole blood samples at $+5^{\circ} \mathrm{C}$. until a sufficient number had accumulated for assay. No attempt was made to determine the precise level of antibiotic present, for in the absence of details of dosage and time of administration no useful conclusions could be drawn from such information.

* Received for publication June 9, 1965.
Blood sulphonamide was detected by the method of Bratton and Marshall (1939), using trichloracetic acid for the preliminary protein precipitation. Serum penicillin was assayed by the plate diffusion technique, using Sarcina lutea as the test organism. Plates were prepared according to the method described by Grove and Randall (1955) and were incubated at $28^{\circ} \mathrm{C}$. for 18 hours. Undiluted serum samples, with and without penicillinase, were placed in wells cut in the medium, and those showing an inhibitory zone neutralized by penicillinase were regarded as containing penicillin. Plates of this type are capable of detecting penicillin in concentrations as low as $\mathbf{0 . 0 1}$ unit per $\mathrm{ml}$.

\section{Results}

Of 34 patients examined in the male and female clinics, twelve showed evidence of serum antibiotic activity; four had detectable penicillin levels, seven showed blood sulphonamide, and one had both penicillin and sulphonamide in measurable quantities. Serum from this last patient gave an inhibitory zone on the Sarcina lutea plate which was completely neutralized by penicillinase. The inhibitory action of many solid media for sulphonamide compounds is well recognized, so that the absence of a residual zone after penicillinase neutralization was not unusual. All patients giving positive results were questioned in detail during their next attendance at the clinic (Table). No serum sample showed antibacterial activity on the Sarcina lutea plate which could not be attributed to penicillin content.

TABLE

DETAILS OF TWELVE PATIENTS GIVING POSITIVE RESULTS

\begin{tabular}{|c|c|c|c|}
\hline Sex & $\underset{\text { Penicillin }}{\text { Serum }}$ & $\begin{array}{c}\text { Blood } \\
\text { Sulphona- } \\
\text { mide }\end{array}$ & Additional History \\
\hline $\begin{array}{l}\text { Male } \\
\text { Male } \\
\text { Male } \\
\text { Male } \\
\text { Male } \\
\text { Male } \\
\text { Female } \\
\text { Female } \\
\text { Male } \\
\text { Male } \\
\text { Male } \\
\text { Female }\end{array}$ & $\begin{array}{l}+ \\
+ \\
- \\
\overline{+} \\
+ \\
+ \\
+ \\
+\end{array}$ & $\begin{array}{l}\overline{+} \\
+ \\
+ \\
\overline{+} \\
+ \\
\overline{+} \\
+ \\
+\end{array}$ & $\begin{array}{c}\text { Nil } \\
\text { Admitted taking wife's tablets } \\
\text { (penicillin and sulphonamide) } \\
\text { Admitted taking tablets } \\
\text { left over from previous visit } \\
\text { Nil } \\
\text { Nil } \\
\text { Nil } \\
\text { Admitted taking husband's tablets } \\
\text { Admitted taking husband's tablets } \\
\text { Nil } \\
\text { Nil } \\
\text { Nil } \\
\text { Nil }\end{array}$ \\
\hline
\end{tabular}




\section{Discussion}

From the relatively small number of patients examined in this series, a total of twelve showing serum antibiotic activity is surprisingly large. Careful questioning revealed that one patient had taken tablets left over from a previous visit to the clinic and, that three had used drugs prescribed for the marital partner. The other eight patients denied having made any attempt at self-treatment, and the source of the antibiotic in their blood must remain a matter for speculation. There is now increasing evidence that certain strains of gonococci have become relatively resistant to penicillin and, although not absolute, this degree of resistance demands higher blood levels for cure of the patient (King and Nicol, 1964). While carefully supervised treatment with oral penicillin may be successful, self-medication can lead only to the emergence of strains exhibiting an even greater degree of resistance. Inadequate and irregular dosage, together with premature cessation of therapy, are among the many factors which will contribute to this loss of efficacy. Even when adequate quantities of a sulphonamide are given for gonococcal infections, the recovery rate is now observed to be poor. In the London investigation of 1946-7 quoted by King and Nicol, the figure was only 14 per cent. of all treated cases. It is unlikely that self-administration by the patient will achieve even this unsatisfactory degree of control.

It is difficult to see how unauthorized treatment can be stopped. Parenteral administration of antibiotics at clinics will reduce the number of patients who can hoard tablets and take them at a later date, or give them to their contacts. However, this is clearly less important than other sources of supply which, at the time of writing, are unknown and impossible to control.

My thanks are due to the Board of Management, Royal Adelaide Hospital, for permission to publish the results of this investigation, and to the medical staff of the venereal diseases clinics, for their interest and cooperation.
This investigation was undertaken by $\mathrm{Mr}$. Peter McDonald, Miss Pauline Wheeler, and Miss Elaine Peterson, medical students at the University of Adelaide, working under my supervision during the summer vacation.

\section{Summary}

The blood of a series of 34 patients attending a VD clinic for gonorrhoea was examined for the presence of self-administered penicillin or sulphonamide. The result was positive in three women and nine men. One man admitted taking tablets left over from a previous visit and one man and two women admitted taking tablets prescribed for the marital partner, but the rest denied having taken any drugs.

The risks and disadvantages of self-medication are discussed.

\section{REFERENCES}

Bratton, A. C., and Marshall, E. K. (1939). J. biol. Chem., $128,537$.

Grove, D. C., and Randall, W. A. (1955). “Assay Methods of Antibiotics: A Laboratory Manual”. Medical Encyclopedia Inc., New York.

King, A., and Nicol, C. (1964). "Venereal Diseases". Cassell, London.

L'auto-traitement par des malades qui se rendent à un dispensaire pour le traitement des maladies vénériennes RÉSUMÉ

Le sang d'un groupe de 34 malades qui se présentèrent à un dispensaire pour le traitement des maladies vénériennes a été examiné pour prouver la présence de la pénicilline ou des sulfamidés administrés sans prescription médicale. Le résultat a été positif dans le sang de trois femmes et neuf hommes. Un des hommes a admis avoir pris des comprimés qui restaient d'une visite précédente, un homme et deux femmes ont admis avoir pris des comprimés prescrits pour leurs conjoints, mais autres ont refusé d'admettre qu'ils avaient pris des médicaments.

Les risques et les désavantages de l'auto-traitement sont discutés. 